\title{
Farlige forsimplinger
}

Af hydrolog Hans Jørgen Henriksen og hydrogeolog Klaus Hinsby begge GEUS, Hydrologisk afdeling.

I temanummeret om klima i GeologiskNyt nr. 2 bragte vi bl.a. en artikel af Ole Humlum fra Institutt for geofag, Oslo Universitet: Klima og $\mathrm{CO}_{2}$. Det følgende indlæg kommenterer denne artikel.

I artiklen Klima og $\mathrm{CO}_{2}$ af Ole Humlum, Oslo Universitet, præsenterer forfatteren i GeologiskNyt 2/08 en spændende og på mange måder sober og grundig redegørelse af de komplicerede sammenhænge mellem $\mathrm{CO}_{2}$ og temperatur, herunder at vanddamp bør indgå på linie med $\mathrm{CO}_{2} \mathrm{i}$ klimamodellerne, så de bedre kan gøre rede for, hvordan det fremtidige klima vil udvikle sig, og hvordan fortidens klima har udviklet sig.

Som hydrolog og hydrogeolog er vi fuldt forstående overfor, at vi kan og skal lære af fortidens klimavariationer, og at vandkredsløbet, drevet af nedbør og temperatur i øvrigt, skal indgå i klimamodelleringen med en procesbeskrivelse og en konceptualisering, der fuldt redegør for diverse feedbackmekanismer, mellem temperatur, nedbør, fordampning, skydannelse, $\mathrm{CO}_{2}$ osv.

Desværre synes Ole Humlums budskab at være, at vi ikke behøver at bekymre os så meget $\mathrm{om} \mathrm{CO}_{2}$-reduktion, fordi klimaændringerne primært styres af naturlige pro- cesser, som vi alligevel ikke kan gøre noget ved. Det, finder vi, er et yderst problematisk standpunkt. Jo - klimaet har udvist stor variation gennem hele Jordens historie, og det har været langt varmere før. Den afgørende forskel er blot, at der dengang ikke levede mennesker på kloden, og at fremtidige klimaændringer kan få meget store konsekvenser for menneskers levebetingelser og den globale økonomi.

Derudover er menneskeheden nu en aktiv medspiller i udviklingen af atmosfærekemien og dermed i reguleringen af Jordens klima.

\section{Upræcise beskrivelser}

Ole Humlum skriver, at Al Gore i sin prisbelønnede film ("Den ubekvemme sandhed") var upræcis i sin beskrivelse af sammenhængen mellem temperatur og $\mathrm{CO}_{2}$ atmosfæren, idet han hævdede, at $\mathrm{CO}_{2}$-koncentrationerne er den dominerende drivende faktor for observerede temperaturstigninger.

Det samme gør sig imidlertid gældende for Ole Humlums artikel, der ganske rigtigt påpeger, at temperaturstigningerne medfører øgede $\mathrm{CO}_{2}$-koncentrationer i atmosfæren. Begge gør sig imidlertid skyldige i forsimplinger, idet påvirkningerne $\mathrm{i}$ virkeligheden foregår begge veje og forstærker hinanden gennem komplekse "feedback"-mekanismer (se fx Scheffer et al. 2006).

Behov for fremsynet vandforvaltning Begge overser dermed, at der faktisk ek- sisterer en gensidig interaktion mellem temperatur og $\mathrm{CO}_{2}$, som i stedet for at give anledning til at vi kan begynde at ånde lettede op, reelt bør øge vores opmærksomhed. Vi vil derfor gerne tilslutte os Ole Humlums skepsis med hensyn til klimamodellerne, men på den anden side advare mod at vi bruger "one-way-link"-tænkning, når vi skal forholde os til fremtiden.

Med de alvorlige konsekvenser, vi muligvis står overfor, er det ikke længere tilstrækkeligt alene at lære af fortiden, nu er det mindst ligeså nødvendigt at forsøge at forudsige den nære fremtid og betydningen af forskellige kilder til usikkerhed, gennem en bedre forståelse af jordens klimasystem, og processerne der regulerer det, så vi på en gradvis og hensigtsmæssig måde kan tilpasse os de forventede klimaændringer i tide.

Eksempelvis er der stærkt behov for fremsynet og adaptiv vandforvaltning, så vi på bedst mulig vis kan planlægge klimasikrede systemer osv., der er robuste og fleksible i forhold til det fremtidige klima. Herved reducerer vi de mulige skader på vandressourcer, miljø og kystnære eller lavtliggende samfund.

Litteratur:

Scheffer, M.; Brovkin, V. and Cox P.M. 2006. Positive feedback between global warming and atmospheric $\mathrm{CO}_{2}$ concentration inferred from past climate change. Geophys. Res. Letters, 33, L10702, doi: 10.1029/2005GL025044. 